\title{
Krótka historia polityczna folkloru muzycznego w Polsce
}

\author{
A short political history \\ of musical folklore in Poland
}

DOI: 10.12775/LL.1.2021.001 | CC BY-ND 3.0 PL

\begin{abstract}
The text discusses the manner in which the music traditions of old country communities were subjected to government actions aimed at the selective incorporation of countryside heritage into mainstream social circulation. The first part of the article briefly describes the selected initiatives and the utilization of music folklore in times of independent Interwar Poland. The next section examines how folk music was forced into the ideology of the new social reality after World War Two, shaped by military and political hegemony of the USSR. The conclusion explores the significance of the relationship between folk music and politics in the context of contemporary phenomena related to globalization and the political processes that accompany it.
\end{abstract}

KEYWORDS: folk music, stylized folklore, cultural policy, Polish folk movement, communism, globalization

Temat „muzyka ludowa a polityka” należy do zagadnień dość nowych, aczkolwiek jest już obecny w literaturze przedmiotu (Dahlig 1998; Kordjak 2016; Nowak 2010). Pojawia się on w kontekście przemian politycznych i wymaga dystansu historycznego. Poniższy esej sprowadzić można do pytania: W jaki sposób względnie zachowawcze tradycje muzyczne społeczności wiejskich zostają poddane działaniom zewnętrznym, odgórnym, mającym na celu selektywne włączenie dziedzictwa wsi do szerszego, ponadlokalnego obiegu społecznego. Oryginalne dziedzictwo mieszkańców niewielkich lecz licznych miejscowości cechujących się pewną odrębnością kulturową przystosowywano lub wręcz wykorzystywano i podporządkowywano celom ideologicznym w nowych realiach politycznych, jakie zaistniały w Polsce, 
zarówno w warunkach niepodległego państwa międzywojennego, jak i w kraju podporządkowanym po II wojnie światowej militarno-ideologicznej hegemonii ZSRR.

Pojęcie „muzyki ludowej” jako sztuki dźwięku właściwej dawnym społecznościom wiejskim bliskie było głównie instrumentalistom (skrzypkom, harmonistom), którzy „obracali” melodiami tanecznymi ku zadowoleniu najbliższego środowiska. Samo słowo „muzyka” na wsi oznaczało nie tylko muzykę jako taką, ale też zabawę taneczną bądź grupę instrumentalistów tworzących kapelę. Ci ostatni, niezależnie od własnych upodobań estetycznych, stanowili „służbę” muzyczną dla lokalnego środowiska, dlatego też byli najbardziej podatni i wrażliwi na zmiany kulturowe ${ }^{1}$. Zamówienia na grę na zabawach i weselach pochodziły z miejscowości odległych nie dalej niż 20-30 km od miejsca zamieszkania „gracza” (termin używany np. w Wielkopolsce). Swoje zadanie muzykanci wypełniali z sumiennością właściwą wiejskim rzemieślnikom, do którego to stanu muzycy pretendowali. Ich muzykowanie nie było „wybieraniem robaczków” (określenie jednego z wykonawców na odtwarzanie muzyki z nut), lecz po prostu graniem, które dodatkowo charakteryzowano czasem określeniami: „z głowy”, „zza ucha”, „z kapelusza”, a w Radomskiem mówiono też, że jest to „wyciąganie do nieba”. Jakość wykonania - tak jak w każdym rzemiośle - zależała od umiejętności i zdolności muzykanta, ujmowanych jako słuch, głos/ton, pamięć, zamiłowanie. Wśród instrumentalistów ludowych powszechna jest opinia, że muzyka, melodie i ich realizacja powinny „smakować” wszystkim słuchaczom i tancerzom. Muzyka ludowa spełnia się tu i teraz, w sytuacji konkretnego wykonania wewnątrz kompetentnej grupy uczestników spotkania. Jej interpretacja kulturowa jest już dodawaniem znaczeń i wartości oraz odkrywaniem wewnętrznej struktury, podobnym do badania okazów mikroorganizmów pod mikroskopem.

Ludowa praktyka muzyczna w dawnym „organicznym” stylu przykuwa uwage obserwatora intensywnością przeżycia, znacznym stopniem improwizacji i pełną identyfikacją wykonawcy z tym, co realizuje. Działania odgórne o charakterze oświatowo-politycznym wprowadzają zaś takie zmiany i uwarunkowania, które osłabiają lub wręcz eliminują wymienione trzy cechy tradycyjnego wykonawstwa (intensywność, improwizacyjność, osobiste utożsamienie). Trzeba jednak pamiętać, że folklor muzyczny w oryginalnym kontekście mógł stanowić siłę nieobliczalną. Zabawy taneczne bywały tak zapamiętałe i żywiołowe (z bitkami włącznie), że budziły sprzeciw części młodzieży wiejskiej już w latach trzydziestych XX w. Zewnętrzne ingerencje polityczne wiązały się z próbami redukcji owej żywiołowości bądź zaprzęgnięcia jej do nowych celów. Górale mają swój termin na pełne zaangażowanie się w akcję muzyczną - to „zatracanie się” (w muzyce, śpiewie, tańcu). W praktyce wokalnej śpiew częściej - jak mawiają śpiewaczki - „cieszył biede”, a nadwyżki energii spalane były w przyśpiewkach, które zawsze miały wymiar indywidualny. Gra i taniec z kolei stanowiły coś na kształt kulturowego narkotyku,

1 Śpiew i repertuar pieśniowy miały charakter bardziej zachowawczy, gdyż stanowiły „własność” całych społeczności wiejskich. W tworzeniu chórów i rozmaitych folklorystycznych zespołów śpiewaczych przeplatały się intencje wewnętrzne, np. potrzeba artyzmu, emblematu, awansu czy wyjścia poza ramy danej społeczności i inicjatywy zewnętrzne, np. oświatowe czy polityczne. Wśród tych ostatnich widoczna jest chęć patronowania, kontrolowania, uzależniania wykonawców przez mecenat, a nawet wykorzeniania dawniejszych formacji kulturowych. 
głównej rozrywki służącej temu, by wytchnąc po pracy, odrzucić choć na jakiś czas monotonię życia.

Muzykowanie rozumiane jako forma wysublimowanej sztuki, autonomiczna dziedzina twórczości, która dzięki mediom (począwszy od wynalezienia druku) może istnieć niezależnie od kontekstu społecznego i bez zanurzenia w życiową prawdę, „nie pasuje” (określenie często używane przez depozytariuszy tradycji) do wspólnotowej kultury słuchu i pamięci muzycznej. Nawet jeśli muzycy wiejscy opanowali pismo nutowe, w praktyce społecznej stawało się ono bezużyteczne. Muzyka w kształcie tradycyjnym nęciła głównie ludzi młodych. Na zabawach tanecznych młodzież się poznawała, zawiązywały się bliższe relacje, przyszłe małżeństwa. Tam też wprawiali się w grze do tańca młodzi instrumentaliści. Starsi natomiast, aktywni bardziej w przestrzeni domowej, służyli młodszym i najmłodszym swoją pamięcią muzyczną, repertuarem pieśniowym bądź instrumentalnym. Muzyka odgrywała też niezwykle istotną rolę w przypadku wesela; obsługiwała i ozdabiała ten kluczowy rytuał, który w XIX stuleciu stanowił święto niemal dla całej wiejskiej społeczności, oraz spełniała oczekiwania dwóch, a nawet trzech pokoleń jego uczestników. Uwagi powyższe odnoszą się do stanu względnej odrębności, samodzielności, samowystarczalności kulturowej małych społeczności wiejskich w okresie międzywojennym. Sformułowałem je na podstawie ok. 500 wywiadów z osobami urodzonymi przeważnie w dwóch pierwszych dekadach XX w. (Dahlig 1993).

Odrębność kultury dawnej wsi przyciągała uwage osób spoza środowiska wiejskiego. Trzeba przy tym podkreślić, że społeczność ta sama w sobie była bardzo zróżnicowana, a jedynie stereotypy panujące w miastach upraszczały wizerunek wsi, co zresztą do dziś jaskrawo uwidacznia się w działalności teatrów ludowych, np. podczas przedstawień na Sejmikach Wiejskich Zespołów Teatralnych ${ }^{2}$.

Polityka - nawet w idealnym wyobrażeniu, jako działanie jednostek i ugrupowań dla wspólnego, imaginowanego przez te ugrupowania dobra społecznego - rozmija się z przeznaczeniem muzyki tradycyjnej. Istotą tej ostatniej jest raczej wzmożenie witalności i woli życia (jednostki, wspólnoty lokalnej) poprzez ekspresje słowno-muzyczne, zawołania, upust energii w tańcu, przez stopienie się grupy w śpiewie, w transie świeckich responsoriów chóralnych, przez płacz (np. lament weselny lub pogrzebowy) czy wzruszenie śpiewanymi napomnieniami dziada odpustowego (Grochowski 2004; Michajłowa 2002). Profesjonalny nurt muzyczny

2 Sejmiki Wiejskich Zespołów Teatralnych (alternatywna nazwa Sejmiki Teatrów Wiejskich) to małe festiwale widowisk ludowych, organizowane w Stoczku Łukowskim (od 1970 r.) i Tarnogrodzie (od 1975 r.; od 1984 r. także jako impreza ogólnopolska) oraz w innych miejscowościach południowej i zachodniej Polski jako sejmiki regionalne. Ruch ten trwa do dziś. Wystawiono ogółem ponad 1000 przedstawień, w zdecydowanej większości o tematyce etnograficznej, ze scenariuszami opracowywanymi przez same zespoły ludowe i częstą skłonnością do wiernej rekonstrukcji przeszłości. Prezentowane widowiska dotyczą obrzędów rodzinnych, zwłaszcza weselnych, zwyczajów dorocznych, prac domowych; pojawiają się też spektakle o współczesnym życiu na wsi oraz kabarety wiejskie. Przedstawienia są przygotowywane samodzielnie w lokalnych społecznościach, jednak opiekę nad nimi sprawują placówki kultury (także instruktorzy teatralni). Merytoryczną konsultacją służy na sejmikach Towarzystwo Kultury Teatralnej w Warszawie; jego prezes, Lech Śliwonik, zredagował następujące publikacje upamiętniające ruch Sejmików Wiejskich Zespołów Teatralnych: Sejmiki Wiejskich Teatrów, Warszawa 1993; Sejmiki Wiejskich Teatrów 2 (lata 1994-1998), Warszawa-Lublin-Tarnogród 1998; Teatr z własnego życia, pamięci, emocji..., Warszawa-Tarnogród 2003; Wczoraj i dzisiaj teatru ludowego, Warszawa-Tarnogród 20o8; Teatr ocalany, Warszawa-Tarnogród 2013; By źródło wciąż biło. Teatr ludowy w Polsce - dawniej, dzisiaj, pytania o jutro, Tarnogród-Warszawa 2018. 
w kulturze ludowej skierowany był również ku najbliższemu audytorium. Dobrym przykładem tej zasady jest działalność lirników (Haj 1993: 110-114, 2007: 38-43), których wystąpienia muzyczne miały piętrową strukturę „suity” i rozwijały się od pieśni nabożnej, przez epikę bohaterską, do repertuaru popularnego (kołomyjki, romanse, przyśpiewki satyryczne); cały seans kończył się zaś modlitwą za zmarłych przodków tych, którzy wysłuchali występu³.

Jak wspomniano na początku, samowystarczalność kultury chłopskiej, podkreślana często przez badaczy folkloru, w XX w. wystawiona została na oddziaływanie polityki i to zarówno tej zewnętrznej, jak i wewnętrznej, czyli oddolnej i inicjowanej przez własne środowisko. Zewnętrzne inicjatywy polityczne względem muzyki ludowej jawią się jako próby podporządkowania niewerbalnej ekspresji kultur chłopskich nowym ideom i wykorzystania jej dla nowych celów poprzez dostosowanie do możliwości odbioru masowego audytorium. Z drugiej strony, po uwłaszczeniu, w warunkach industrializacji i rozwoju środków komunikacji (drogi żelazne, z których korzystał już Oskar Kolberg) mieszkańcy wsi z własnej inicjatywy porzucali towarzyszący im od dzieciństwa dźwiękowy krajobraz. Wyzbywali się swojej fonosfery wraz z jej kontekstem kulturowym, które pierwotnie nie były przedmiotem wyboru, lecz stanowiły elementy ich losu.

Z samego środowiska wiejskiego od przełomu XIX i XX w. wyłaniał się ruch polityczny (ludowy), który do swych emblematów zaliczał „swojszczyznę” muzyczną, chętnie praktykowaną np. w uniwersytetach ludowych kształcących liderów wsi (inicjatywa Zofii i Ignacego Solarzów). Obecny w tych instytucjach śpiew wymykał się już z oryginalnego kontekstu środowiskowego i sytuacyjnego (obrzędy, zabawy). Nową przestrzeń kulturową dla muzyki chłopskiej (w tym góralskiej) stworzyły także teatry i chóry, organizowane początkowo odgórnie (Związek Teatrów i Chórów Włościańskich, Lwów 1907), potem również oddolnie, przez samych liderów kultury lokalnej, zwłaszcza nauczycieli wiejskich. Regionalne Związki Teatrów Ludowych wraz z Instytutem Teatrów Ludowych (założonym w 1929 r. przez Jędrzeja Cierniaka, Jerzego Zawieyskiego, Jadwige Mierzejewską i innych) podejmowały działania polityczne, których cele z dzisiejszej perspektywy można określić jako: 1) podniesienie samoświadomości kulturowej środowisk wiejskich (które w okresie II Rzeczpospolitej stanowiły 70\% ludności Polski), 2) zapewnienie spektakularnej reprezentacji wsi w kulturze narodowej i masowej (np. organizowane od $1927 \mathrm{r}$. dożynki prezydenckie w Spale, zainicjowane nota bene na fali integracji politycznej po zamachu majowym w 1926 r.), 3) przeciwstawianie sie „międzynarodowej tandecie" i masowemu przemysłowi rozrywkowemu, który nie sprzyjał tworzeniu głębszych, lokalnych więzi społecznych (Dahlig 1998).

Z punktu widzenia muzycznego najważniejsza jest transformacja jednogłosowej, spontanicznej pieśni wiejskiej w wielogłosowe utwory dedykowane chórom ludowym ${ }^{4}$. Większość kompozytorów i etnomuzykologów (wśród tych ostatnich np.

Warto dodać, że w XIX w. lirnicy podejmowali taką działalność w całej Galicji (Przerembski 1995: 43-56), natomiast w okresie międzywojennym władze sowieckie, nie mogąc ich skutecznie kontrolować, wszczęły prześladowania i dopuściły się w latach trzydziestych XX w. masowych i zorganizowanych morderstw tych prawdziwie ludowych artystów (Noll 1993: 16-26; Mazur-Hanaj 2009: 397-414; Dahlig 2008: 13-21). 
Łucjan Kamieński i Marian Sobieski) traktowała opracowanie „skromnej” pieśni jako twórczy gest wobec małych ojczyzn. Dla muzykalnych mieszkańców wsi chór był „oknem na świat”. Z kolei dla dyrygentów, kierowników szkół, starostów czy polityków działalność chórów stanowiła wyraz suwerenności artystycznej środowisk ludowych, a w szerszym wymiarze politycznym świadectwo dorównywania kulturze muzycznej byłych zaborców. Po odzyskaniu przez Polskę niepodległości w 1918 r. już samo swobodne manifestowanie w pieśni języka polskiego (np. przy uświetnianiu różnych jubileuszów) budziło ogólne wzruszenie.

Podobny cel polegający na kreowaniu samodzielności artystycznej kultury wsi widoczny jest w scenariuszach widowisk ludowych, zarówno tych drukowanych w „Teatrze Ludowym”, jak i notowanych przez grupy entuzjastów tego typu inscenizacji, a także tych realizowanych „z głowy”. Zauważalne w takich przedstawieniach nadwyżki charakteryzacji i gestów (wynikające z braku nagłośnienia) mogą dziś nie przekonywać estetycznie, ale w dekadach międzywojennych działalność ta była świadectwem samodzielnych wysiłków artystycznych. Z punktu widzenia polityki kulturalnej władz oświatowych, a przede wszystkim Jędrzeja Cierniaka, celem organizowanego w latach trzydziestych XX w. ruchu amatorskich teatrów ludowych było zastąpienie „sztuczek dla ludu” (produkowanych przez przedsiębiorczych miejskich literatów i wystawianych przez zespoły wiejskie dla pozyskania funduszy) prezentacjami zaczerpniętymi z własnej kultury, które demonstrowały podmiotowość społeczności wioskowej. W ten sposób powstawały scenariusze widowisk na kanwie obrzędów rodzinnych (np. ponad 50 wesel regionalnych w latach 1925-1939), dorocznych (np. gaik, sobótki, kolędowanie), zwyczajów wspólnej pracy (np. prządki) (Dahlig 1998: 84-90, 290-377). Fenomenem wiejskiego teatru etnograficznego jest szczególna ciągłość tej formy oraz jej interesująca obecność także w XXI w. Ruch ten, wyrastający bezpośrednio ze społeczności wiejskich, wspierają różne placówki kultury, w tym Towarzystwo Kultury Teatralnej w Warszawie, a widowiska, których osią tematyczną jest życie na wsi, są nadal układane i wystawianie (np. w Warszawie podczas fesiwalu „Zwyki” w Teatrze Polskim); ich poziom zadowoliłby dziś wybrednego krytyka teatralnego.

Od okresu międzywojennego działalność młodzieży w wiejskich domach ludowych oraz w ruchu świetlicowym wiązała się z pewnym awansem społeczno-artystycznym. Ten pierwszy etap przeobrażania i stylizacji folkloru miał oparcie we wspólnym działaniu społeczności wiejskich oraz miejscowych przewodników (zwłaszcza nauczycieli) oraz w programie oświaty pozaszkolnej pilotowanym przez państwowe kuratoria ${ }^{6}$. Śpiew chóralny oraz nauka pieśni i inscenizacji stanowiły atrakcję dla ówczesnej młodzieży wiejskiej. W seminariach nauczycielskich, do których trafiali wyróżniający się młodzi mieszkańcy wsi, obowiązkowa była m.in. nauka gry na skrzypcach, a nauczycieli śpiewu zachęcano (po reformie oświatowej

państwa, że pojawiały się jako odrębna pozycja w rocznikach statystycznych z okresu międzywojennego.

5 Pojęcie używane w okresie międzywojennym oznaczające wystąpienia, których uczestnicy-aktorzy uzgadniali tylko wstępnie, o czym będzie się mówiło, a następnie swobodnie wprowadzali poszczególne kwestie, stosując improwizację w zakresie doboru słów.

6 Sytuacja taka miała miejsce np. w Bukowinie Tatrzańskiej i na byłych Ziemiach Wschodnich II Rzeczpospolitej. 
w 1934 r.) do zbierania pieśni ludowych, co stanowiło element realizacji programu „nachylenia środowiskowego” szkoły. Aktywność folklorystyczna ówczesnych pedagogów stanowiła echo podobnych działań w krajach niemieckojęzycznych. Śpiewniczki pieśni ludowych z 16 różnych regionów Polski wydane w latach 1934-1938 pod redakcją Karola Hławiczki świadczyły o poszanowaniu cech gwarowych ludowej poezji, co skądinąd było trudne do zaakceptowania dla szkolnych polonistów. Do programów nauczania od roku 1933/1934 chętnie włączano adaptacje tańców regionalnych i lokalnych zwyczajów dorocznych (np. przedstawienia sobótkowe na zakończenie roku szkolnego, ścinanie kani na Kaszubach czy mazurskie widowisko bożonarodzeniowe „Jutrznia na Gody”).

Strajki chłopskie w 1936 r. na Podkarpaciu przyspieszyły działania polskiego rządu zmierzające do pozyskania przychylności związków młodzieży wiejskiej. W ramach tej koncepcji organizowano ogólnopolskie zjazdy zespołów regionalnych, podczas których muzyka i tańce odgrywały wybitną rolę, tworzono pierwsze festiwale folkloru (od 1937 r.), kontynuowano imponujące dożynki w Spale. Od 1935 r. urządzano również „Święta Gór”, które cieszyły się dużym zainteresowaniem władz wojskowych z racji tego, że górale uchodzili za znakomitych żołnierzy. Kwitnący folkloryzm sprzyjał krystalizowaniu się specyficznego dla poszczególnych regionów repertuaru wokalnego i tanecznego (suity regionalne), a także składów kapel i ubiorów ludowych. Owo „wyławianie” folkloru w celu prezentowania go szerokiej widowni można rozumieć dziś jako sterowaną politycznie inkorporację elementów kultury ludowej do kultury masowej, która odwołuje się do „uśrednionego” minimum kompetencji każdego członka projektowanej przez nią wspólnoty politycznej. Nie wydaje się, aby pod tym względem sytuacja w Polsce odbiegała w okresie międzywojennym od tej w Czechosłowacji, na Węgrzech czy w Rumunii. Wszędzie tam przedstawiciele władz i propagatorzy ideologii państwowych z zainteresowaniem i życzliwie, choć zarazem ze specyficznym paternalizmem, spoglądali na ulotną kulture muzyczną wsi oraz zastanawiali się, jak przystosować ją do nowych celów integracji politycznej.

W ogólnej perspektywie przemiany tradycji ludowej oraz jej funkcji i warunków transmisji można ująć jako proces czterofazowy. Faza pierwsza to stan wewnętrznej samoregulacji społecznej w warunkach pewnej izolacji. W fazie drugiej ugruntowuje się świadome zainteresowanie kulturą (muzyką) ludową, zarówno ze strony odbiorców zewnętrznych, jak i wewnątrz środowiska wiejskiego, co związane jest z faktem, że samodzielna tradycja chłopska przestaje być oczywistością. Faza trzecia obejmuje działania instytucjonalne wspierające wejście spuścizny kulturowej wsi w obieg ponadlokalny (regionalny, narodowy, państwowy, medialny itp.) oraz dotyczy przystosowania owego dziedzictwa do nowych kontekstów artystycznych, społecznych i politycznych. W przystosowaniu tym chodzi w szczególności o kompensowanie zaniku praktyki muzycznej w życiu codziennym poprzez ekspozycję jej pamiątek na scenach festiwali, przeglądów, konkursów itp. Faza czwarta i ostatnia to przechodzenie lokalnej spuścizny kulturowej do najszerszej, globalnej transmisji, a także do indywidualnej praktyki kompozytorskiej, twórcy bowiem, mimo pełnej

7 Na potrzeby uroczystości dożynkowych Kazimierz Moszyński zaprojektował dwanaście bram regionalnych, a Polskie Koleje Państwowe udzielały 80\% zniżki na dojazdy. 
suwerenności artystycznej, rozwijają się w kontekście określonych uwarunkowań społeczno-historycznych, a więc wpływ na nich mają także inspiracje źródłami pochodzącymi z kultur „typu ludowego”.

Powyższy schemat culture change zakłada proces powolny, organiczny, naturalny i polega w sumie na uwalnianiu dóbr kulturowych od ich oryginalnych (pierwotnych) uwarunkowań społecznych. Innymi słowy, charakteryzuje się przewagą czynników wewnętrznych nad czynnikami zewnętrznymi, w rodzaju agresji, wojny czy rewolucji, które wywołują gwałtowne zmiany określane eufemistycznie jako „zderzenia kulturowe”.

Katalog perwersyjnych zastosowań muzyki ludowej nie jest pusty. Zagłuszanie popularną muzyką odgłosów torturowania więźniów w siedzibie Gestapo w Alei Szucha w Warszawie czy pogodne marsze w wykonaniu „brygad artystycznych”, umilające strażnikom liczenie więźniów wychodzących do katorżniczej pracy w gułagach zapisały się jako najbardziej przewrotne manipulacje cudowną dyspozycją człowieka do muzykowania i tworzenia muzyki. Totalitaryzmy wymyśliły, w jaki sposób spożytkować ową dyspozycję (np. orkiestry dęte, śpiew) do budzenia „sztucznego entuzjazmu” czy rozweselonej (choć zdyscyplinowanej) dzikości w pochodach i manifestacjach (Dahlig 2010: 41-54). Ich organizatorzy korzystali z powszechnej jeszcze w pierwszej połowie XX w. umiejętności śpiewu, propagując ideę pieśni masowej jako antidotum na tango lub jazz. Wkrótce jednak z idei tej pozostało tylko skandowanie. Indagowani przeze mnie powojenni przesiedleńcy z dawnych województw wschodnich II Rzeczpospolitej wspominali o konieczności udziału wszystkich muzyków i kapel ludowych w obchodach pierwszomajowych, które miały miejsce w 1940 r., po wcieleniu tych ziem do ZSRR jesienią $1939 \mathrm{r}$. Oczywistym celem organizowania śpiewających i skandujących pochodów było zagłuszanie osobistej refleksji ich uczestników oraz ułatwianie im pozytywnego wczucia się w tłum i chętnego poddawania dyspozycjom politycznych „dobrodziejów”. Osobiście traktowałbym tę strategię jako iście szatańską karykaturę kultu religijnego, porównywalną z prawem mordercy do noszenia ubioru ofiary.

Powyższa diagnoza ma jednak pewne ograniczenia, które wypływają z istoty muzyki. Po zakończeniu straszliwej w skutkach II wojny światowej w małych społecznościach potrzeba muzykowania, śpiewu oraz tańca bywała uderzająca i analogiczna do tego, w jaki sposób na Zachodzie Europy jazzem odreagowywano I wojnę światową. W latach 1944-45 wyzwalaniu polskich ziem spod niemieckiej okupacji i ich zajmowaniu przez ZSRR nie towarzyszyła przecież pełna, obiektywna i szybka informacja. Ludzie na wsi i w miastach przede wszystkim spostrzegali, że wojna i pięć lat okupacji właśnie się kończą, nie wiedzieli natomiast, że przebiegła polityka prowadzona w Polsce przez NKWD polegała na niszczeniu lokalnych liderów (wliczając w to członków PSL oraz ugrupowań narodowych), „instalowaniu” własnej kadry oraz na promowaniu ludzi pozbawionych wszelkiej własności (np. bezrolnych, których dzięki przywilejom można było pozyskać bez reszty), a także tych, których za pomocą szantaży można było zmusić do służenia nowej władzy (np. członków w działającej w czasie okupacji niemieckiej policji granatowej). Jedynie tam, gdzie do obsady stanowisk nie starczało „swoich” ludzi, dopuszczano miejscowe, sprawdzone siły. Polityka taka dotyczyła również placówek kultury, gdzie delegowano towarzyszy, którzy nie najlepiej sprawdzili się na pierwszym froncie walki 
ideologicznej. Polityczne cele związane z tworzeniem ludowych zespołów, kapel czy orkiestr mogły jednak pozostawać nieznane ich uczestnikom, którzy po wojenno-okupacyjnych traumach chcieli po prostu śpiewać, grać i tańczyć. Zapewne nie wszyscy wiedzieli, że w katowniach UB giną właśnie ich rodacy, najbardziej zasłużeni w walce o niepodległość kraju i najlepiej przygotowani do sprawowania władzy. Wiedziano tylko, że transparenty i portrety są wymienne, a potrzeby rekreacji permanentne. Muzyka ludowa, zarówno w pierwszej dekadzie powojennej, jak i na przełomie XX i XXI w., czyli w okresach doniosłych transformacji społeczno-kulturowych, zawierała neutralny potencjał, innymi słowy była ponad czy też poza konkretnym ustrojem politycznym, a na wielu ludzi działała jak balsam. Mogła być co prawda wykorzystywana, przeformułowywana, stylizowana, dekontekstualizowana, lecz jej podstawowy gest i poryw, który utrwalił się chyba już w XVI w., pozostał ten sam, choć oczywiście był aktualizowany.

Przy całym zaangażowaniu polskich komunistów (lub komunistycznych „przebierańców”) w instalację radzieckiego systemu politycznego w naszym kraju oraz ich początkowo ukrywanym dążeniu do kolektywizacji gospodarstw rolnych, podjęli oni jednak pewną decyzję, którą należy zauważyć i docenić. Chodzi mianowicie o pozwolenie na zorganizowanie badań dokumentacyjnych i sfinansowanie ogólnopolskiej Akcji Zbierania Folkloru Muzycznego (AZFM), która miała miejsce w latach 1950-1954. Życzeniem „sponsorów” było jedynie to, by w ramach owej akcji rejestrować również „pieśni buntu” i utrwalać zadowolenie z władzy ludowej w rolniczych spółdzielniach produkcyjnych. W ten sposób polityczne realia i decyzje władz związane z bezcenną dla zachowania fonograficznego wizerunku polskich wsi działalnością Jadwigi i Mariana Sobieskich zreferował Ludwik Bielawski (1973: 28-48). Pod względem politycznym ogólnopolską dokumentację folkloru wspierali też Zofia Lissa, organizatorka muzykologii na Uniwersytecie Warszawskim, i Aleksander Jackowski, twórca periodyku „Polska Sztuka Ludowa”.

Decyzję o powołaniu AZFM (1 stycznia 1950 r.) poprzedziły następujące działania: badania terenowe i nagrania na płytach decelitowych, prowadzone głównie w Wielkopolsce'; nagłośnienie problemu poprzez zorganizowanie w Warszawie w 1949 r. Festiwalu Muzyki Ludowej, na którym prezentowano autentyczne wykonania muzyki wiejskiej; apele i usilne starania etnomuzykologów o podjęcie tzw. dokumentacji ratunkowej.

We wczesnych latach pięćdziesiątych różnego rodzaju przedwojenne inicjatywy, takie jak Centralne i Regionalne Archiwum Fonograficzne Łucjana Kamieńskiego (1930), akcja nagrywania folkloru na terenie całej II Rzeczpospolitej prowadzona przez Juliana Pulikowskiego (1934-1939) czy apele etnografów o powołanie Instytutu Badania Pieśni Ludowej (1935), zaczęto wcielać w życie z dużym rozmachem, w kompletnie innej sytuacji politycznej. Celem tych działań było także to, by legitymizować nową władzę. Podobnie ruch folklorystyczny, zainicjowany w okresie

8 W tym miejscu warto może dodać, że przekonanie o „ponadustrojowym” (ponadpolitycznym) wymiarze folkloru motywowało także Juliana Krzyżanowskiego (doświadczonego grozą wydarzeń $\mathrm{XX}$ w.) do niesłychanie owocnych wysiłków badawczych w domenie folklorystyki, w tym też do założenia i wypromowania „Literatury Ludowej”.

9 Wielkopolska to region, z którego pochodziły przedwojenne zbiory fonograficzne, utracone w czasie okupacji niemieckiej. 
międzywojennym, nabrał rozpędu w skali ogólnopolskiej wraz z inauguracją w 1953 r. występów Państwowego Zespołu Ludowego Pieśni i Tańca „Mazowsze”.

Niezależnie od uwarunkowań politycznych, rezultaty AZFM - przechowywane dziś w Instytucie Sztuki Polskiej Akademii Nauk (IS PAN) - okazały się trwałe i cenne; stanowią one, obok Archiwum Polskiego Radia, największy w Polsce korpus źródeł muzycznych, gwarowych, folklorystycznych, pochodzący ze zdecydowanej większości ziem współczesnej Polski. Po zakończeniu AZFM w 1955 r. zbiory fonograficzne, liczące 46 ooo pieśni i melodii instrumentalnych zarchiwizowanych na taśmach magnetofonowych, pod względem rozmiarów podwoiły kolekcje zgromadzone w Poznaniu i Warszawie w latach 30. XX w. (liczące łącznie 24 ooo nagrań na wałkach woskowych i płytach decelitowych), które zostały zniszczone w czasie II wojny światowej ${ }^{10}$. Pojawiające się w nagraniach z AZFM jedynie sporadycznie „przyśpiewki wdzięcznościowe” (adresowane do Stalina i Bieruta) mają dziś takie samo znaczenie, jak eksponaty z Galerii Sztuki Socrealizmu w Muzeum Zamoyskich w Kozłówce; przypominają, że „postać świata” przemija, a tyrania może okazać się w końcu śmieszna. Profesor Anna Czekanowska wspominała zresztą, że wiernopoddańcze przyśpiewki bywały dziełem studentów biorących udział w AZFM.

Julian Pulikowski w swojej monografii opublikowanej w Heidelbergu, jeszcze przed osiedleniem się w Polsce (Pulikowski 1933), przewidywał intensywną implementacje pieśni ludowej do życia społeczno-politycznego po zwycięstwie narodowego socjalizmu w Niemczech. Złudzeniom na temat „renesansu” folkloru w Niemczech i we Włoszech uległa także Cezaria Baudouin de Courtenay Ehrenkreutz Jędrzejewiczowa (1936). Narzucające się porównanie w sposobie traktowania folkloru pomiędzy Niemcami po 1933 r. a systemem radzieckim wprowadzonym w Polsce we wczesnych latach pięćdziesiątych nie jest jednak uzasadnione. Przede wszystkim nie było w Polsce, nawet we wczesnej fazie opresji komunistycznej, tej radości maszerowania do piosenek ludowych, jaka istniała w III Rzeszy. Przystosowanie folkloru do maszerowania, zainicjowane w Legionach (Sankiewicz-Frąckowska 1978: 49-142), a promowane w polskim repertuarze szkolnym od 1934 r. było nieporównanie skromniejsze niż w Niemczech hitlerowskich. Pompatyczne akademie ku czci narodowego socjalizmu w porównaniu do peanów stalinowskich w Polsce to jakby opera seria w stosunku do opera buffa, dramat muzyczny w stosunku wodewilu. Polaków uratował przed totalnym zakłamaniem m.in. ich folklor - dostatecznie żywy, aby nie mógł być całkowicie zmanipulowany. Folklor nie tylko miejski, uchwycony przez Tyrmanda czy Nowakowskiego, ale właśnie praktyczna pamięć kultury wsi, przekrój uczuć ludzkich, wraz z humorem a nawet autoironią, zakotwiczonymi w tekstach i melodiach pieśni, chętnie niegdyś przyswajanych ${ }^{11}$.

10 Aktualnie zbiory fonograficzne IS PAN liczą już ponad 100 ooo fonogramów, od 1990 r. archiwizowanych także w postaci nagrań wideo.

II „Literatura Ludowa” ośmiela mnie do przytoczenia prawdziwego zdarzenia z ustnej pamięci rodzinnej. Mój ojciec, Włodzimierz Wojciech Dahlig, inżynier chemik, udał się jesienią I952 r. do Tarnowa, by wizytować tamtejszą fabrykę. Wieczorem poszedł z kolegą do kina. Zaskoczeni, zamiast białego ekranu, widzą stół, krzesło, karafkę z wodą. Wchodzi starszy pan i zapowiada referat „Udział Polaków w Rewolucji Październikowej”. Czytanie przedłuża się, słuchacze klaszczą po każdym akapicie. Starszy pan spogląda zakłopotany na publiczność: „Proszę państwa, ja mam żonę i dzieci, ja muszę to odczytać”. Zapadła cisza, referat gładko dobiegł końca. 
W powojennej Polsce istniała nierzadko ciągłość personalna w stosunku do dekad międzywojennych. Na przykład Jadwiga Mierzejewska, pomysłodawczyni tanecznej inscenizacji folkloru w Instytucie Teatrów Ludowych, układała programy dożynek centralnych organizowanych na Stadionie Dziesięciolecia. Z kolei Tadeusz Sygietyński, komponujący suity-wiązanki melodii ludowych dla przedwojennego radia oraz utwory zamawiane przez tę najbardziej dynamiczną wówczas instytucję muzyczną, stworzył wraz z Mirą Zimińską zespół „Mazowsze”, produkt zarazem swojski, lojalistyczny (wobec ZSRR), jak i eksportowy (kierowany do Polonii). Pierwsza wymiana płyt między radiofoniami europejskimi w latach 30 . XX w. dotyczyła właśnie muzyki ludowej (opracowanej). Jej polityczna rola spełniała się zatem w nawiązywaniu działań międzynarodowych, polegała na przezwyciężaniu izolacji, uchylaniu „żelaznej kurtyny” (działającej niestety w obie strony) oraz na inicjowaniu korzystnej dla wszystkich mobilności zespołów folklorystycznych. Już V Światowy Festiwal Młodzieży i Studentów w 1955 r. w Warszawie, na którym prezentowali się m.in. czarnoskórzy jazzmani z USA i zespoły ludowe z Jugosławii, zapowiadał ukryty w folklorze powiew wolności ${ }^{12}$.

W dziejach politycznych PRL folklor i muzyka ludowa pełniły funkcję wentyla bezpieczeństwa ${ }^{13}$. Gdy następowało jakieś zderzenie o charakterze konfliktu, awarii, „przesilenia”, uruchamiano mechanizm określany dobrze dziś znanym słowem „poluzowanie”. Po odwilży październikowej w 1956 r., w czasie której oszczędzono nam (w odróżnieniu od Węgrów) widoku czołgów radzieckich w Warszawie, za wczesnego Gomułki nastąpiło usztywnienie polityczne, jednak jakby „na osłodę” represje i działania cenzury omijały ruch regionalny (np. na Kaszubach czy Śląsku). Wówczas mogła pojawić się także m.in. „Literatura Ludowa” z jej ożywczą regionalistyczną tendencją ${ }^{14}$. W tym kontekście warto się też zastanowić, czy małe ojczyzny z ich kulturą ludową nie wpływały na postawy i działalność polityczną sekretarzy PZPR. Przykładem może być choćby Galicja jako macierz ruchu ludowego, pryncypialne (także w polaryzacjach pańsko-chłopskich) Podkarpacie, które uformowało Władysława Gomułkę, albo górniczy pragmatyzm i okcydentalizm Śląska, który umożliwił Edwardowi Gierkowi ponurą sukcesję po Gomułce.

W latach 6o. XX w. bardzo istotny okazał się spór wokół znaczenia obchodów Tysiąclecia Państwa Polskiego, którego głównymi stronami były władze kościelne i polityczne ${ }^{15}$. W owej „wojnie o millenium” nurt folklorystyczny był pojednawczy.

12 Warto zauważyć, że kultura ludowa, która do końca lat 8o. XX w. była bezpieczną dla sekretarzy partyjnych sferą dotowania, jest wykorzystywana w ten sposób również w XXI w. po zmianie ustroju politycznego. Przykładem mogą być kapele ludowe w strojach regionalnych podróżujące z politykami do Brukseli.

$13 \mathrm{~W}$ innym kontekście przedstawił tę sprawę jeden z greckich folklorystów na seminarium w Kazimierzu Dolnym nad Wisłą (ok. 1985 r.), który stwierdził, że gdyby w radiu usłyszał rano muzykę ludową, pomyślałby, że nastąpił przewrót polityczny.

14 Warto przy tym odnotować, że stosunkowo wysokie nakłady ówczesnych czasopism umożliwiają i dziś skompletowanie pierwszych roczników tego periodyku.

15 Trzeba dodać, że w niepewnym pochodzie ku samorządności polskiej, Kościół katolicki stanowił ariergardę chroniącą społeczeństwo przed nienawiścią walki klasowej wykreowaną przez totalizm materialistyczny. Za uchronienie się od tej nienawiści Kardynał Stefan Wyszyński dziękował Bogu. Lektura „Trybuny Ludu” z tamtego czasu nasuwa osobliwą refleksję, iż krytyka postawy prymasa formułowana przez tę partyjną agendę w sposób dość szczery a raczej niezamierzony więcej mówiła o niej samej niż o adresacie zakamuflowanych inwektyw. 
Państwowe zespoły, takie jak „Mazowsze” czy „Śląsk” przetrwały ówczesne „zawirowania” (notabene termin bardziej taneczny niż polityczny). Zastanawiałbym się, czy w sporze o millenium (Noszczak 2002) nie sprawdza się (w tym wypadku bardzo korzystnie) powiedzenie, że gdzie dwóch się bije, tam trzeci korzysta. Na przykład Oskar Kolberg, którego ojca, Juliusa Colberga, określono jako „akatolika” (w księdze parafialnej w Przysusze), jawi się jako sprawiedliwy beneficjent tego konfliktu. W 1960 r. Rada Państwa podjęła uchwałę o reedycji i dalszej publikacji ogromnej spuścizny etnograficznej tego wiernego wyznawcy Kościoła Ewangelicko-Augsburskiego ${ }^{16}$, pragnącego zasłużyć się słowiańskiej ojczyźnie.

Po tzw. wydarzeniach grudniowych (1970 r.) w 1971 r. przyzwolono na to, aby na scenach w lokalnych domach kultury śpiewać kolędy, co jeszcze w latach 60. było nie do pomyślenia. Później stało się to zresztą przyczyną kłopotów tych członków PZPR odpowiedzialnych za kulture i sztukę, którzy do tego dopuścili. Ten okres to również przywracanie oryginalnej wersji folkloru w Polskim Radio, odstępowanie od emitowania wyłącznie jego stylizowanych postaci oraz promowania jedynie zespołów pieśni i tańca, jako wdzięcznego emblematu kultury socjalistycznej (skądinąd chętnie i dziś przyjmowanego przez szeroką publiczność). W latach 7o. następuje wzrost zainteresowania muzyką wiejską w wersji in crudo; poza tym, tak w mediach (radio), jak i na scenach folklorystycznych, w sposobie prezentowania kultury ludowej zaczęto eksponować indywidualności twórcze (stworzono pojęcie twórcy ludowego). W szerszym światowym wymiarze pojawiła się wówczas idea ochrony dziedzictwa niematerialnego, nieopatrznie i bezmyślnie dotąd dewastowanego. Ogólnopolski Festiwal Kapel i Śpiewaków Ludowych w Kazimierzu nad Wisłą (istniejący od 1967 r.) eksponował już w tytule perspektywę personalną, co było zasługą poznańskich etnomuzykologów oczarowanych wielkopolską kulturą dudziarską oraz inicjatorów pierwszego konkursu koźlarzy w Kopanicy w 1937 r. Prawdziwie ogólnopolska impreza kazimierska, organizowana w renesansowym miasteczku, połączyła indywidualizm z narodową zachowawczością i kulturą wspólnotowego śpiewu Lubelszczyzny. Jadwiga i Marian Sobiescy (Marian Sobieski zmarł niestety w 1967 r., gdy festiwal kazimierski miał pierwszą edycję) oraz młodsi wychowankowie etnomuzykologii byli słusznie przekonani, że oryginalność i autentyzm pozostaną walorami najbardziej istotnymi dla trwania folkloru. To dzięki Sobieskim w 1948 r. rozległ się solowy śpiew i gra dudziarza wykonującego pieśń U drzwi Twoich stoję Panie, który wraz z szumnym udziałem miejscowej orkiestry dętej zamykał lokalne dożynki (nagranie utrwalone na płycie decelitowej znajdującej się w zbiorach IS PAN).

Dla polaryzujących się w Polsce od połowy lat 70. XX w. poglądów politycznych muzyka, taniec i teatry ludowe obecne na festiwalach, przeglądach i konkursach stanowiły przestrzeń koncyliacyjną. Reforma administracyjna z 1975 r., tworząca 49 województw, promowała nowe „małe regionalizmy”. Przedstawiciele władz politycznych nadal otwierali i zamykali imprezy folklorystyczne. Znad scen powoli jednak znikały motywujące hasła na temat dobroczynnej roli i szlachetnych intencji PZPR. Z lat 7o. pamiętam znamienny szczegół z pogranicza folkloru i polityki. Mirosław Nalaskowski, pracujący wówczas w Wojewódzkim Domu Kultury we

16 Jak wskazała Arleta Nawrocka-Wysocka (2014: 81-95), Kolberg redagował też śpiewnik ewangelicki. 
Włocławku, w perspektywie planowanych na 1980 r. ogólnopolskich dożynek w Lipnie (nie doszły do skutku z powodu wybuchu strajków) podjął się zorganizowania w 1977 r. konferencji naukowej „Kultura duchowa Ziemi Dobrzyńskiej”. Cenzura zakwestionowała tytuł spotkania ze względu na pojawiające się w nim słowo „duchowa”, zgodziła się natomiast, gdy zmieniono je na agnostyckie pojęcie „niematerialna”. I tak definiowanie negatywne, poniekąd redukcjonistyczne, cenione notabene w traktatach teologicznych, sprawdziło się w warunkach konfliktu ideologii, i to nie tylko w kontekście ideologii komunistycznej, ale także w szerszym planie międzynarodowym, czego przykładem jest Konwencja o Ochronie Dziedzictwa Niematerialnego UNESCO ${ }^{17}$.

U schyłku lat 70. pojawiły się w ruchu folklorystycznym pierwsze retrospekcje z terenów wschodnich II Rzeczpospolitej (wcześniej temat objęty cenzurą PRL). We Wrocławiu w 1980 r. wystawiono inscenizację Wesela tarnopolskiego; w Lidzbarku Warmińskim od 1978 r. odbywają się Zajazdy Cymbalistów, zainicjowane przez Marynę Okęcką-Bromkową z Rozgłośni Olsztyńskiej Polskiego Radia. W czasach stanu wojennego i PRON-u (Patriotyczny Ruch Odrodzenia Narodowego) oraz w okresie prowadzonej przez Michaiła Gorbaczowa polityki głasnosti tematykę kresową częściowo zwolniono z cenzury, by zaspokoić potrzebę ekspresji dumy z politycznych dokonań I i II Rzeczpospolitej. W latach 8o. scenariusze widowisk ludowych musiały być nadal składane w Głównym Urzędzie Kontroli Publikacji i Widowisk, jednak nie były już jak dawniej analizowane łącznie z tekstami przyśpiewek, a cenzorzy powoli rozglądali się za nowym zajęciem. W stanie wojennym miało też miejsce znamienne wydarzenie na festiwalu w Kazimierzu. W 1982 r. Józef Burszta zachęcił swych krajan z Grodziska Dolnego do zaprezentowania Lamentu więźniów jęczących, czyli pieśni religijnej wchodzącej w skład cyklu śpiewów wykonywanych przy zmarłym; pieśn ta, zarówno w życiu, jak i na kazimierskiej scenie, śpiewana była pod przewodnictwem Kazimierza Śmiałka, który był również cymbalistą. W 1985 r. Burszta zachęcił też do wystawienia w Rzeszowie widowiska o siedzących pod kościołem dziadach proszalnych; była to pierwsza tego typu inscenizacja (z Grodziska Dolnego) w ruchu folklorystycznym.

W latach 8o. XX w. można było zauważyć, że ranga przedstawicieli władzy zasiadających w pierwszych rzędach krzeseł na lokalnych imprezach folklorystycznych jest coraz niższa. Mimo to w ostatniej dekadzie XX w. oraz w bieżącym stuleciu w czasie kampanii wyborczych cały czas organizuje się imprezy folklorystyczne, które przyciągają korowody mówców zapewniających, jak bliskie są im korzenie kultury narodowej. Obok szczerości, częściej widać tu krygowanie się przed potencjalnymi wyborcami. W ostatnich latach lokalne imprezy folklorystyczne, promujące tradycyjny, retrospektywny przekaz i repertuar, miewały najczęściej niewielką publiczność (czasem złożoną głównie z samych wykonawców ${ }^{18}$ ), ich organizatorzy

17 Warto na marginesie zauważyć, że angielski termin intangible (ulotny, nieuchwytny) przetłumaczono na język polski jako niematerialny, co jest pochodną terminologii ekonomicznej (ang. intangible assets to wartości niematerialne).

18 Nasuwa się tu analogia do konferencji naukowych, w których uczestniczą sami referenci. Warto przy tym odnotować, że sprowokowane pandemią spotkania naukowe online są ciekawym doświadczeniem, które nieco zmienia sytuację; jednak w przypadku folkloru taka formuła pozbawiona kontaktu face to face jest tylko kroplówką stosowaną w celu pielęgnacji kultury. 
zwykle mogli jednak liczyć na życzenia miejscowego starosty. Na większe imprezy zawitał czasem poseł na Sejm RP, pochodzący z danej ziemi, której poświęcone było śpiewaczo-taneczno-obrzędowe wydarzenie.

Swoistą celebracją polityczną były i są gminne dożynki. W późnych dekadach $\mathrm{XX}$ w. często stanowiły one pole do popisu dla liderek zespołów śpiewaczych o zacięciu literacko-poetyckim. Opowiadano mi, że dawniej przedstawiciele władzy partyjnej i państwowej czasem obrażali się, słysząc treść prezentowanych pieśni, nie pojmowali bowiem, że na dożynkach zawsze można było wyśpiewać swój krytycyzm i bez żadnych konsekwencji wyrazić swój satyryczny i prześmiewczy temperament (obowiązywało to teoretycznie też na weselu).

Podsumowując, jako pewną propozycje usystematyzowania relacji polityki i muzyki ludowej, wyróżniłbym zestaw sześciu wariantów owych relacji, który w przyszłości należałoby rozwinąć:

1. zastosowanie muzyki popularnej i folkloru jako perwersyjnej maski, za pomocą której próbuje się ukryć dręczenie ludzi przez politycznych oprawców;

2. użycie muzyki ludowej jako dodatku do bezpośredniej propagandy (np. emitowanej przez „kołchoźniki” w kołchozach i innych miejscach);

3. znakowanie muzyką ludową integracji państwowej, awansu społecznego chłopów, przewrotu politycznego;

4. wprowadzanie muzyki ludowej jako akcentu ideologicznego do kampanii wyborczych w warunkach demokracji (zwłaszcza w przypadku stronnictw ludowych);

5. komercyjne używanie muzyki ludowej jako tła w marketingu i w kampaniach reklamowych;

6. rekonfiguracja stylów muzycznych (w tym różnych stylów muzycznego folkloru), jako poszukiwanie nowych jakości w krajobrazie artystycznym (muzyka folkowa), które - mimo wiary w czyste intencje artystyczne - nie jest wolne od współczesnych ideologizacji, uwarunkowanych zarówno racjami osobistymi, jak i interesem ekonomicznym (przypadki „zaokrętowania” się muzyki ludowej w kulturze masowej).

Wszystkie te warianty zdarzyły się w przeszłości i mogą się powtarzać, ich ponowienia nie oznaczają jednak wchodzenia do tej samej rzeki.

Osobną kwestią, pozostającą w polu relacji „muzyka ludowa a polityka”, jest sytuacja aktualna i zespół zagadnień związanych z globalizacją oraz towarzyszącymi jej procesami politycznymi. Charakterystyczne dla owych procesów jest choćby pojawienie się rynkowej etykiety World Music (1980) oraz przechodzenie od pojęcia muzyki ludowej, bliższego Europie, do pojęcia muzyki tradycyjnej, bliższego Azji. Ważnym momentem w tym procesie był 1984 r., kiedy to w Seulu uchwalono zmianę nazwy międzynarodowej organizacji zajmującej się muzyką ludową: w miejsce International Folk Music Council (od 1947 r.) zdecydowano się na International Council for Traditional Music, działający pod auspicjami UNESCO. Istotne wydaje się zwłaszcza to, że ta ostatnia organizacja jest bardziej otwarta na kultury Azji i Afryki niż Europy. Trzeba jednak zauważyć, że współcześnie w kontekście relacji między polityką a muzyką tradycyjną dyskutowane są nie tyle kwestie wartości 
niematerialnych czy napięcia między etnocentryzmem a kosmopolityzmem, co raczej samo funkcjonowanie tradycji muzycznych w mediach masowych. Przykładem takiego podejścia mogą być badania przeprowadzone w Szwecji, które doprowadziły Rogera Wallisa i Krister Malm $(1984,1992)$ do sformułowania koncepcji medializacji (mediaization), opisującej zmiany tradycji muzycznych, a zwłaszcza sposobów ich transmitowania i dystrybucji, jakie zachodzą pod wpływem mediów masowych.

Zmiany te sprawiają m.in., że wyróżnione przez Waltera Wiorę (1959) dwa byty folkloru (pierwszy - in situ, w miare zachowawczy, drugi - przetworzony, upowszechniany także poza środowiskiem wiejskim, nazwany później folkloryzmem) rozmnożyły się w toku rozwoju technologicznego do czterech: obok folkloru i folkloryzmu, mamy bowiem do czynienia z niezależnym od nich obrazem muzycznych tradycji w przemyśle fonograficznym oraz funkcjonowaniem muzyki ludowej w przestrzeni internetu. Wszystkie te tendencje dostrzegamy obecnie i w Polsce. Trzeba jednak zauważyć, że niektóre regionalizmy, dające pożywkę praktyce tradycyjnego muzykowania oraz kulturze śpiewu i służące budowaniu poprzez folklor określonych wspólnot, zachowują nadal żywotność i są wykorzystywane zarówno w ochronie więzi lokalnych, jak i w budowaniu i podtrzymaniu atrakcyjności turystycznej regionu. Muzyka etniczna/ludowa/tradycyjna zajmuje wyraziste miejsce w krajobrazie kulturalnym naszego kraju. W zasadzie uwolniła się ona obecnie od ideologicznego „płaszcza”, jaki dawniej nakładało na nią monocentryczne państwo, i w XXI w. przyczynia się do realizacji konkretnych potrzeb estetycznych mniejszych lub większych grup społecznych. Jest jednak zarazem poddana nowym procesom zmian kulturowych i technologicznych.

\section{BIBLIOGRAFIA}

Bielawski, L. (1973). Działalność Jadwigi i Mariana Sobieskich na polu dokumentacji i badań polskiej muzyki ludowej. W: J. i M. Sobiescy, Polska muzyka ludowa i jej problemy (s. 28-48). Kraków: Polskie Wydawnictwo Muzyczne.

Baudouin de Courtenay Ehrenkreutz Jędrzejewiczowa, C. (1936). Dwie kultury i dwie nauki. Warszawa: Wydział Wychowania Polityczno-Obywatelskiego przy Zarządzie Głównym Z.P.O.K.

Dahlig, P. (1993). Ludowa praktyka muzyczna w komentarzach i opiniach wykonawców w Polsce. Warszawa: Wydawnictwo Instytutu Sztuki PAN.

Dahlig, P. (1998). Tradycje muzyczne a ich przemiany. Między kultura ludowa, popularna i elitarna Polski międzywojennej. Warszawa: Wydawnictwo Instytutu Sztuki PAN.

Dahlig, P. (2008). Śpiewacy wędrowni, lirnicy i ich repertuar jako odwzorowanie świata. W: K. Turek, B. Mika (red.), Muzyka religijna - między epokami i kulturami. T. 1 (s. 13-21). Katowice: Uniwersytet Śląski.

Dahlig, P. (2010). Music and Totalitarianism. Artificial Enthusiasm. Musicology Today, 7, 41-54.

Grochowski, P. (2004). Poruszyć skały. O sposobach i okolicznościach wykonywania pieśni dziadowskich. Czas Kultury, 20(2-3), 73-81.

Khay, M. (1993). Lirnyts'ka tradytsiya yak fenomen ukrayins'koyi dukhovnosti. Rodovid, 6, 38-43.

Khay, M. (2007). Muzychno-instrumental'na kul'tura ukrayintsiv (fol'klorna tradytsiya). Kyyiv-Dpohobych: Kolo.

Kordjak, J. (red.) (2016). Polska - kraj folkloru? Warszawa: Zachęta - Narodowa Galeria Sztuki. 
Malm, K., Wallis, R. (1984). Big sounds from small peoples: The music industry in small countries. London: Constable.

Malm, K., Wallis, R. (1992). Media policy and music activity. London: Routledge.

Mazur-Hanaj, R. (2009). The lirnyk-dziad and his songs (trans. J. Comber). W: P. Dahlig (ed.), Traditional Musical Cultures in Central-Eastern Europe. Ecclesiastical and Folk Transmission (pp. 397-414). Warsaw: University of Warsaw. Institute of Musicology.

Michajłowa, K. (2002). Dziad wędrowny jako postać mediacyjna w kulturze ludowej Słowian. W: Kapełuś, M., Engelking, A. (red.), Fascynacje folklorystyczne. Księga poświęcona pamięci Heleny Kapetuś (s. 101-108). Warszawa: Agade.

Nawrocka-Wysocka, A. (2014). Nurt ewangelicki w dokumentacji Oskara Kolberga. Polski Rocznik Muzykologiczny, 12, 81-95.

Noll, V. (1993). Moral'nyy avtorytet ta suspil'na rol' slipykh bardiv v Ukrayini. Rodovid, 6, 16-26.

Noszczak, B. (2002). „Sacrum” czy „profanum”? Spór o istotę obchodów millenium polskiego (1949-1966). Warszawa: Towarzystwo Naukowe Warszawskie.

Nowak, T. (2010). Polish Folk Music in the Period of Polish People' Republic - Look from Afar. Musicology Today, 7, 29-137.

Przerembski, Z. (1995). Korbova Lira u Pol'shchi. Rodovid, 2, 43-56.

Pulikowski, J. (1933). Geschichte des Begriffs Volkslied im musikalischen Schriftum. Ein Stück deutscher Geistesgeschichte. Heidelberg: Winter.

Sankiewicz-Frąckowska, M. (1978). Polskie pieśni żołnierskie z okresu I wojny światowej. Próba systematyki i kwalifikacji przeobrażeń. W: A. Czekanowska, L. Bielawski (red.), Studia etnomuzykologiczne (s. 49-142). Wrocław: Ossolineum.

Wiora, W. (1959). Der Untergang des Volkslieds und sein zweites Dasein. In: W. Wiora (ed.), Musikalische Zeitfragen. Vol. VII. Das Volkslied heute (pp. 9-25). Kassel: Bärenreiter-Verlag. 